\title{
Agonistic Critiques of Liberalism: Perfection and Emancipation
}

Thomas Fossen ${ }^{1}$

Utrecht University

Published in Contemporary Political Theory, 2008, 7, (376-394)

http://www.palgrave-journals.com/cpt/journal/v7/n4/abs/cpt200815a.html

\begin{abstract}
Agonism is a political theory that places contestation at the heart of politics. Agonistic theorists charge liberal theory with a depoliticization of pluralism through an excessive focus on consensus. This paper examines the agonistic critiques of liberalism from a normative perspective. I argue that by itself the argument from pluralism is not sufficient to support an agonistic account of politics, but points to further normative commitments. Analyzing the work of Mouffe, Honig, Connolly, and Owen, I identify two normative currents of agonistic theory: emancipatory agonism, aimed at challenging violence and exclusion, and perfectionist agonism, aimed at the cultivation of nobility. From a normative perspective the former presents an internal challenge to liberalism, while the latter constitutes an external challenge to liberalism by providing a competing account of the ends of politics. Recognition of the distinction between emancipatory and perfectionist agonism is crucial in assessing the purchase of agonistic critiques of liberalism. Furthermore, this analysis draws us beyond the simple opposition between contestation and consensus. It is not simply a question of valuing genuine pluralism and therefore criticizing consensus; rather the question comes to be: what are the ends of politics?
\end{abstract}

\section{Introduction}

Agonism can be defined as a political theory that does not place any institutions, procedures, principles, or values beyond political contestation; that precludes final closure on any question. In doing so, it challenges some of the fundamental commitments of the liberal paradigm as embodied in political liberalism and deliberative democracy, most fundamentally the idea that the legitimacy of a political regime relies on a consensus among rational or reasonable citizens. In first instance, the debate takes the following form: agonistic theorists criticize the liberal focus on consensus as a precondition for politics, in the form of an overlapping consensus among reasonable persons with different comprehensive doctrines

\footnotetext{
I would like to express my gratitude to Herman Siemens and Bert van den Brink for invaluable discussions and commentary. I would also like to thank David Owen and two anonymous reviewers for their helpful comments.
} 
(Rawls), or as the telos implicit in political deliberation (Habermas). While explicitly acknowledging pluralism as a condition of contemporary politics, liberal theorists, on the agonistic account, actually restrict 'genuine' or 'radical' pluralism in important but unacknowledged ways. In order to let pluralism flourish we need a form of politics that does not ultimately rely on consensus but is essentially contestatory. The central opposition in the debate hence appears to be between contestation and consensus; between genuine or radical pluralism and restrictive or reasonable pluralism. ${ }^{2}$

At least, this is the initial picture that arises from the terms in which the challenge is presented by agonistic theorists. However, it is my contention that this picture obscures the questions that are at stake in this debate. In this paper I examine the agonistic critique of liberalism by uncovering the normative commitments that inform it. Such an analysis should set out the terms of the debate and thereby facilitate further engagement between these perspectives on politics. My approach is distinctive in that it does not aim to defend either agonism or liberalism; the aim is rather to bring out what is at stake in this debate from a normative perspective and to probe the prospects for a more productive dialogue between advocates of agonistic politics and liberal theorists.

I begin this enquiry by examining what appears to be the starting point and motivation of some agonistic theorists: a genuine appreciation, or valuation, of pluralism as expressed by Chantal Mouffe, William Connolly, and Bonnie Honig. I show that this commitment to pluralism by itself is insufficient to explain a commitment to contestatory politics and argue that the valuation of pluralism points to an underlying normative commitment, namely a commitment to emancipation. Emancipation should be conceived broadly here: as a permanent attempt to lay bare and redress the harms, injustices or inequities caused by exclusions and restrictions of pluralism. It seems that such a case, if it can be made convincingly (a big if), would constitute an internal challenge to liberals, who cannot turn a blind eye to harm generated by their favored political arrangement. Once this commitment is recognized, a contrast can be drawn with an alternative type of agonistic theory with a

2 Assessments of the agonistic critique have come mainly from the deliberative perspective (Brady, 2004; Dryzek, 2005; Knops, 2007). See also Schaap's response to this debate (2006) and his recent review article (2007). Deveaux (1999) examines agonism as a very broad category, including Arendt's theory of political action and Barber's republicanism. Villa (1999) critically examines agonism but takes its critique of liberalism for granted. Finally, Acampora (2003) and Siemens (2001) examine agonism in relation to Nietzsche. 
different normative basis; perfectionist agonism, exemplified by the work of David Owen. Perfectionism here signifies a commitment to the cultivation and continuous improvement of citizens' virtues and capacities. Perfectionist agonism provides a more fundamental challenge to liberalism because it provides a competing account of the ends of politics, suggesting that it constitutes an external rather than internal challenge to liberal theory from a normative standpoint. Recognition of this distinction between emancipatory and perfectionist agonism is crucial in assessing the purchase of agonistic critiques of liberalism and the prospects for agonistic theory. Furthermore, the analysis of the normative commitments of agonism in these terms draws us beyond the simple opposition between contestation and consensus. It is not simply a question of valuing genuine pluralism and therefore criticizing consensus; rather the question comes to be: what are the ends of politics?

\section{Pluralism as a Value}

Why are we to affirm a politics of contestation? The prima facie answer put forward by agonistic theorists appears to be that liberalism pays lip-service to the 'fact of pluralism' but does not value pluralism in itself. Through its focus on consensus it fails to make room for 'genuine pluralism' (Honig, 1993, 130). What is meant by a valuation of pluralism, and what reason is it meant to supply to affirm political contestation over consensus? As a starting point, an elaboration of the value of pluralism is a useful hermeneutic device to introduce elements of agonistic theory. However, it will become apparent over the course of my argument that the agonistic concern with pluralism cannot be understood in abstraction from underlying normative and theoretical commitments.

This type of argument from pluralism is put forward most persistently by Chantal Mouffe. The difference between agonistic democracy and liberalism, as Mouffe presents it, is that liberalism (at least in the Rawlsian variety) acknowledges pluralism 'merely as a fact', whereas an agonistic account of politics takes pluralism as a value in itself:

'Envisaged from an antiessentialist theoretical perspective, [...] pluralism is not merely a fact, something that we must bear grudgingly or try to reduce, but an axiological principle. It is taken to be constitutive at the conceptual level of the very nature of modern democracy and considered as something that we should celebrate and enhance. This is why the type of pluralism that I am advocating gives a positive status to differences and questions the objective of unanimity and homogeneity, which is always revealed as fictitious and based on acts of exclusion.' $(2000,19)$ 
Yet it is not immediately clear what a valuation, celebration, and enhancement of differences amounts to. Specifically, we need to ask: pluralism of what? To address this question the passage needs to be read in light of Mouffe's wider work. The quoted passage reflects several conceptions of difference that operate at different theoretical levels in her work. Firstly, pluralism is valuable because it is 'constitutive at the conceptual level of the very nature of modern democracy'. The notion of pluralism at the conceptual level, for Mouffe, refers to the fact that liberal democracy is informed by two distinct traditions of political thought which affirm different and sometimes conflicting principles: popular sovereignty and individual liberty. Two further conceptions of difference are suggested by the last sentence of the passage, namely those differences that run counter to 'unanimity and homogeneity'. These too link up to recurrent sets of arguments in her work. Against unanimity Mouffe affirms a conception of difference as disagreement which she contrasts with the role of a rational consensus in contemporary theories of political liberalism and deliberative democracy (2000, 80-107). This conception of difference thus plays at the level of public reason; a valuation of difference undermines the consensual conception of public reason espoused in liberal theories. And against homogeneity Mouffe affirms a conception of identity to which difference is essential $(2000,12-13)$. Proliferation of identities requires difference as a precondition. Thus, the conceptions of difference at stake here refer to the constitutive principles of liberal democracy in the first instance, to individuals' political beliefs and attitudes in relation to public reason in the second, and to differences of identity in the third (this is not to deny that these conceptions are related, for instance in the sense that individuals' beliefs are tied to their identity, but it makes sense to distinguish them because Mouffe provides arguments on these different levels). A closer examination of each should make clear in what sense pluralism is to be taken as an 'axiological principle', as Mouffe proclaims.

Mouffe's notion of difference 'at the conceptual level' of liberal democracy points to what she calls the 'paradox of liberal democracy': 'that liberal democracy results from the articulation of two logics which are incompatible in the last instance and that there is no way in which they could be perfectly reconciled.' (2000, 5, cf. 18, 36-57) These logics are the product of two traditions that embody principles which are fundamentally at odds: political liberty and popular sovereignty $(2000,10)$. The tension between them arises because no political arrangement can be conceived in which both are perfectly satisfied; individual liberties limit the extent to which the people as a whole can exercise its will. Mouffe's account of this inherent tension in liberal democracy is inspired by Carl Schmitt, but for her this points 
to an essential and productive aspect of liberal democracy, rather than spelling its demise. The democratic paradox is crucial for Mouffe because it goes beyond the simple fact of the diversity of conceptions of the good as a condition with which liberal democracies must cope, and poses 'plurality' as a condition of possibility of liberal democracy (2000, 36-59).

For Mouffe, the fact that these different, irreconcilable logics fundamentally underlie liberal democracy legitimates conflict and division $(2000,19)$. If both are essential, yet no arrangement can be made that fully satisfies both, then there is a conceptual space in between in which legitimate positions can be staked out. Any specific arrangement is only a temporary resolution of this tension which poses a particular interpretation of these principles as hegemonic and which therefore can be legitimately contested from a different position within this symbolic space $(2000,5)$. For Mouffe, it is precisely this interplay between conflicting interpretations of fundamental liberal-democratic principles that is the defining feature of liberal democracy; this contest is what makes pluralism 'constitutive at the conceptual level'.

Thus the sense in which difference, or pluralism, is of value to democracy 'at the conceptual level' is not so much the historically contingent fact that different traditions, affirming different principles, constitute contemporary liberal democracy, but rather that democracy as a practice is conceived as a contest between interpretations of these constitutive principles. This is why Mouffe stresses the point that there can be no final reconciliation, no single right balance between these principles. If politics were conceived to be based on a single set of compatible or reconcilable principles, there would be no room for contesting interpretations of these principles, and politics would amount to the mere implementation of them. In short, politics would be administration - the public sphere would be depoliticized. This is precisely what liberalism does on the account of agonistic theorists.

Can this account illuminate Mouffe's claim that pluralism should be taken as a principle of value? It appears so, if one affirms her conception of democratic politics; if political contestation on fundamental liberal-democratic principles should be valued, then so should the tension that is constitutive of it. But this raises the question why we should affirm this conception of liberal-democracy in the first place - the question of the ends of politics. To affirm, at this point, a contestatory politics on the basis of a valuation of pluralism would be circular; it is not pluralism as an axiological principle that underlies a contestatory conception of politics, but it rather seems to be taken as valuable because it enables politics in this sense. At this point, Mouffe's affirmation of pluralism as a value points to further normative commitments. 
Before moving on to reveal an underlying commitment to emancipation in the next section, we need to probe Mouffe's theory further in order to determine in what sense pluralism could be considered a value. As we saw, difference operates at several levels in Mouffe's work. The second prominent conception of pluralism in her theory operates at the level of public reason. The conception of difference that informs it is difference as disagreement. It involves an empirical and a theoretical claim. The empirical claim is that individuals' beliefs and attitudes differ so widely that there is no substantive consensus on a set of principles to govern society. This is an obvious point that is widely acknowledged in liberal thought. ${ }^{3}$ The theoretical claim is more consequential, namely that no consensus on such principles can be sanctioned by rationality or reason (Mouffe, 2000, 22-31). This rejection is widely shared among agonistic theorists (Connolly, 1991, 13; Honig, 1993, 127). Many liberal theorists, in line with John Rawls, conceive a shared conception of justice as an ideal, a prerequisite for a just political arrangement that allows for a plurality of conceptions of the good (Rawls, 1999a, 394). In his early work, Rawls deals with the empirical condition of pluralism by abstracting from the plurality of conceptions of the good through a hypothetical decision procedure to determine principles of justice that are rationally acceptable to all (Rawls, 1999b). In his later work, he accommodates pluralism somewhat differently by postulating a conception of justice that is compatible with a plurality of reasonable world views, thereby constituting an 'overlapping consensus' (Rawls, 2005). In either case, the empirical possibility of individuals failing to comply with this conception of justice is faced by drawing a distinction between either rational and irrational, or reasonable and unreasonable. According to agonistic theorists this distinction has deleterious effects, disqualifying those who disagree on principles of justice as 'unreasonable' or 'irrational'. In short, this conception of pluralism with regard to public reason involves a critique of rationalism - the claim that a particular political arrangement is sanctioned by reason, to the exclusion of others. ${ }^{4}$

Two main theoretical points can be distinguished within this critique of rationalism: the indeterminacy of reason, and the power-ladenness of reason. The first can be seen as an extension and radicalization of Rawls's pluralism. It accepts Rawls's view that different

3 Clearly, Rawls, for instance, does not deny the existence of rival conceptions of justice as an empirical condition (1999b, 5, 17, see also Waldron, 1999, 149-163).

4 It should be pointed out that rationalism is criticized as a starting point for political theorizing from within the liberal tradition as well (Friedman, 2000; Waldron, 1999, 149-163; van den Brink, 2005). For a critique of Mouffe's arguments on this point, see Knops (2007). 
conceptions of the good and different philosophical, religious, and moral views result from the exercise of human reason (Rawls, 2005 36-7), but rejects the notion that it is possible to avoid or circumvent such differences where principles of justice are concerned. In other words, it holds with Rawls that the good is underdetermined by reason, but, contrary to Rawls, claims the same of justice (Connolly, 1991, 161). The notion that rational deliberation must in the end yield conclusive answers on this point, acceptable to every reasonable person, is rejected. In the terms of agonistic theorists, there is 'undecidability' involved (Honig, 1993, 89-96, 105-107; Mouffe, 2000, 31).

The second way in which the critique of rationalism is made is more contentious. It is underpinned by a conception of power, inspired by Nietzsche and Foucault, in which any social construction is constituted through discourse, and discourse is an expression of relations of power. Power is taken to be 'constitutive' of any social construct, including a conception of justice or a sense of identity (Laclau and Mouffe, 2001, 107). As such, power pervades society through and through. An original position such as Rawls proposes, as a site for rational deliberation, free from the distortions of power, cannot be conceived on this account, because power is not merely the coercive force of the state or the bargaining-strength of individuals in deliberation (as it is in liberalism). According to Mouffe, any 'rational' or 'reasonable' consensus is itself constituted through power-relations (2000, 21-22, 31, 49, 104).

What is this argument meant to establish? The distinction between an overlapping consensus based on reasonableness and fanatic adherence to an unreasonable doctrine clearly constitutes an exclusion. This point is readily conceded by liberals. The claim agonistic theorists make is that this exclusion, posing as a result of the exercise of reason, is actually constituted through contingent relations of power. They intend to face up to these relations of power, rather than to veil them behind a mark of moral legitimacy. As Mouffe sums up: 'Consensus in a liberal-democratic society is - and will always be - the expression of a hegemony and the crystallization of power relations. The frontier that it establishes between what is and what is not legitimate is a political one, and for that reason it should remain contestable.' $(2000,49)$ This argument against rationalism is thus underpinned by an ontology of power, in which difference as disagreement (beyond what is characterized as reasonable) dissolves into difference as a challenge to dominant power-relations.

We should distinguish between two claims here. Does the thesis of the power-ladenness of reason entail an evaporation of the critical purchase of the concept of reason? In other words, 
can any claim to reason be reduced to relations of power, as an expression of hegemonic power-relations? Or is the claim weaker, namely that reason is never pure, that power cannot be eradicated from it completely, but that reason retains some critical force? The second understanding suggests that, although power always comes into play in some sense, not only power is concerned. It is not always clear which claim agonistic theorists are making (Mouffe sometimes appears to hold the strong version $(2000,49))$. However, the weaker claim may be sufficient if the aim is to show that any claim to reason, especially in the case of the political, is contentious and should be contestable. ${ }^{5}$

However, the observation that power-relations pervade social life does not in itself provide any criteria for judging particular constellations of power. In other words, even if a presumed rational consensus is actually a sedimentation of power-relations, this does not mean that it should be devalued. Only if a putatively rational consensus amounts to exclusions that are illegitimate does this amount to a devaluation of such a consensus, meaning that difference as disagreement can be positively valued because it addresses such exclusions. But this requires more than the empirical fact that there is no consensus in conjunction with the claim that a consensus cannot be sanctioned by reason. It requires a criterion for distinguishing legitimate from illegitimate relations of power. In this context, then, pluralism as a value by itself does not form a basis for the affirmation of contestation, but points to further normative commitments (identified below as emancipation and perfection).

I now turn to the last important role which difference plays in Mouffe's theory, namely in her conception of identity. This, too, is a point that can be widely found among agonistic theorists, particularly in Connolly's influential account. Identity refers to the way individuals perceive themselves and are perceived by others (Connolly, 1991, 64). It refers to the person's sense of who he or she is. Part of this are the individual's beliefs about politics and morality. Two points that agonistic theorists make are of central importance here: the constitutive role of difference within and between identities, and the constitutive role of power. These points are derived from a theory of meaning based on Derrida, and a theory of power based on Nietzsche and Foucault. According to this theory of meaning, meaning is constructed out of difference. In other words, the meaning of a term is defined in opposition to other terms; it has no definitive meaning or reference by itself, and thus it cannot be understood in isolation. This gives rise to the idea of a 'constitutive outside' (Mouffe, 2000, 12-13; 2005, 15); the

5 Tully (2002) makes a similar argument in which he situates the activity of critical reasoning within social practices. 
recognition that what is different or other in relation to something is at the same time a necessary condition for its existence. Transposed to the realm of human identities, the idea is that individual or collective identity, an 'I' or a 'we', is always formed in relation to others, a 'them'-a relation which, according to Mouffe, is always possibly one of antagonism; identity is constructed against some other (rather than merely beside or apart from it). The other thereby forms to an extent what it means to belong to 'we'; it forms a constitutive outside. The reason for emphasizing this point is that difference, thereby, is constitutive of identity (Connolly, 1991, 64). Consequently, difference occurs not merely between different identities, but within them as well. At the same time, identity-formation takes place in a social context - the individual or group is immersed in a context of discourses which structure the development of identities. At this point the ontology of power comes back in. In short, identities are not fixed and given; they are contingent, malleable constructs in a context of power-relations (Mouffe, 1995, 33).

Considered apart from its underpinning by a theory of meaning, the claim that identities are pluralistic and potentially conflicting, not simply between individuals, but within them, is plausible. Indeed, as Amartya Sen (2006, 4-5, 18-39) points out, it is evident in the way identities are experienced. Individuals never conceive themselves simply in terms of one affiliation or characteristic, and are sometimes torn between conflicting aspects of their identity. What then, of the claim that these plural identities are constituted by relations of power? On the one hand, it is impossible to deny the crucial influence of social context on identity. On the other, Sen takes the plural and contingent nature of identity to point to the importance of individual choice in shaping an individual's identity $(2006,19)$. Against this, Connolly and Mouffe would rightly say that identity is prior to choice, that choice is always informed by an individual's sense of identity. Without delving too deep into this contentious debate on identity-formation, it appears that agonistic theorists need not deny all human agency in shaping identity (short of pure choice), if what they are after is the recognition of a constitutive tension of difference within and between identities, on the one hand, and an affirmation of the crucial influence of context on the other.

To return one last time to Mouffe's valuation of pluralism; what does it mean to affirm difference as a value in the context of identity? In the first place, it means recognizing difference as constitutive of and necessary for identities. Yet, affirming it as a value goes beyond acknowledging it as constitutive. It does not follow from the fact that difference is required as a precondition for identity and the political that we should value difference. Why 
should we take the proliferation of identities in society as a political value? A liberal might say that to value an individual is not necessarily to value his or her sense of identity-what qualifies the individual as valuable is, for example, the moral personhood that stems from being a member of the human race. The agonist could retort that the individual cannot be abstracted from his or her identity; this is what constitutes him or her as an individual. Still, it is not exactly clear what could give this account of pluralism of identity its normative force, nor what its implications would be with respect to liberalism. We could speculate that the proliferation of identity is a necessary condition for human flourishing. But the valuation underlying this is not pluralism as an axiological principle, but rather some conception of human flourishing. Again, the valuation of pluralism in this context points to normative considerations beyond simply affirming differences between or within individuals as valuable.

After working through the three dimensions of Mouffe's proclaimed valuation of difference - the constitutive principles of liberal democracy, disagreement and public reason, and identity-we still have no conclusive answer as to how pluralism is to be taken as a value in itself, as something worthy of stimulation. It turns out that to focus solely on the argument from pluralism as a motivation for an agonistic account of politics is misleading. On close inspection the valuation of pluralism is a rather weak basis for critique. Furthermore, despite their explicit valuation of pluralism, agonistic theorists cannot and do not maintain that any difference is valuable in itself. Even on their account, some sense of measure is set on pluralism. Mouffe, for example, rejects the most extreme pluralism or "valorization of all differences' (2000, 20). And Connolly, similarly, points out that affirming his conception of identity 'does not entail the celebration of any and every identity' (1991, 14). Each of the elaborations of pluralism as a value points to further normative commitments.

\section{Emancipation and depoliticization}

What, then, are the underlying normative commitments of agonistic theories? I propose that in order to make sense of the contemporary agonistic critique of liberalism we need to draw a distinction between emancipatory agonism and perfectionist agonism. In the current section and the next I will elaborate this classification, beginning with the emancipatory variety. It is fair to say that emancipatory agonism is the most prominent current, represented by Mouffe, Honig, and Connolly. Their emancipatory commitment is best understood from the perspective of their critique of liberalism. 
Agonistic theorists generally share a diagnosis of liberalism in terms of a depoliticization of pluralism, which is bound up with their conception of the political. ${ }^{6}$ In contrast to a conception of the political as a set of governing institutions and practices, the agonistic conception of the political can be seen as a mode of social interaction characterized by disruption and antagonism (Honig, 1993, 123, 200; Mouffe, 2005, 9). Agonistic theorists conceive of political space as being opened up wherever clashes occur within social practices. Politics on this conception is thus a break with automatism, with routine, with settled practice. It runs through the liberal as well as the Arendtian distinction between public and private because disruptive action cannot be confined to a secluded domain. ${ }^{7}$ Political action is conceived as contestation, and requires tension as a precondition (recall Mouffe's account of a constitutive tension at the heart of democracy). Given that Rawlsian liberalism is committed to achieving a consensus on the principles according to which public institutions operate, a public conception of justice, it is fair to say that Rawls attempts to eliminate or, rather, preempt contestation over these principles (Rawls, 2005). In Habermas's deliberative democracy, citizens are expected to come to agreement through procedures that reflect ideal conditions of rational deliberation as closely as possible and that are themselves beyond contestation (Habermas, 1996). So, if one adopts an agonistic conception of the political as contestation, it is clear that Rawls and Habermas attempt to depoliticize- to place beyond contestation - public institutions and practices, a set of basic democratic procedures, at least with regard to the principles according to which they are judged. They attempt to circumvent the tension inherent in the fact of pluralism by reference to a reasonable consensus that is not afflicted by this condition. In other words, they attempt to construct an institutional framework free of tension and antagonism. According to the agonistic conception of politics, both thereby eliminate contestation on some of the most fundamental questions of politics, replacing politics with administration or 'displacing politics' (Honig, 1993).

How different this understanding of politics is from the liberal conception, and how easily misunderstandings can arise from conflating the two, can be seen in Brian Barry's criticism of the call to politicize culture by 'theorists of difference' such as Iris Young (whose conception of the political is akin to but not identical with that of the agonistic theorists considered here), which he finds 'chillingly reminiscent of Nineteen Eighty-Four' (Barry, 2001, 15). A

\footnotetext{
6 The critique of depoliticization has historical roots that extend beyond the current agonistic critique of liberalism, for instance, in the work of Arendt (1998) and Schmitt (1996).

7 For an agonistic critique of this distinction in Arendt, see Honig (1993, 118-124).
} 
totalitarian state as presented in Orwell's classic, for Barry, represents a deep intrusion of politics into society and culture, whereas from an agonistic perspective, it represents an attempt to completely depoliticize society by repressing all contest, by closing every site of contestation and reducing political and social life to pure administration. Yet, both views are in a sense correct if we distinguish between politics as a set of governing institutions and practices and politics as a mode of social interaction.

The question is how this characterization of liberalism as depoliticization obtains its critical charge. The crucial step in the emancipatory agonistic critique of liberalism lies in the problematization of this strategy of depoliticization by identifying it as a source of harm, injustice, or subordination. This problematization involves two moments. First, agonistic theorists argue that we must acknowledge that politics is inevitably bound up with violence and exclusion. For Mouffe, this links up with the ontology of power identified in the previous section. We need to face up to the reality of ineradicable power-relations and the fact that any political association involves exclusion (Mouffe, 2000, 248; 2005, 10-14). Honig argues in a different vein that political theories cannot avoid engendering remainders, resistances to attempts at systematic organization (1993, 213 n. 1). For both, politics has an inherent tension that is potentially antagonistic. Second, an affirmation of the ineradicability of violence and exclusion actually helps to mitigate suffering and harm, while to pretend that a harmonious political arrangement is possible is actually to perpetuate and aggravate it. This point connects with the critique of rationalism discussed above, identifying a rational consensus as always fictitious and exclusionary (Connolly, 1991, 13; Honig, 1993, 127; Mouffe, 2000, 19). We can identify two mechanisms through which, emancipatory agonistic theorists claim, democratic citizens are disempowered due to liberal depoliticization: masking and branding. On the one hand the pretension of a rational consensus hides pervasive and necessary exclusions in any political regime behind a mask of supposed agreement (Mouffe, 2000, 248). On the other, insofar as violence and exclusion do come into sight, those subject to it are branded with a mark of 'irrationality' or 'unreasonableness' (Honig, 1993, 148). These mechanisms can be seen as restrictions of pluralism; its victims are identified by their difference from the norm of rationality or reasonableness. Hence agonists' call for a valuation of pluralism that goes beyond Rawlsian 'reasonable pluralism'.

This analysis of the critique of depoliticization reveals an emancipatory ideal at its core. Emancipation should be conceived broadly here: not simply as a call to establish (socioeconomic) equality among individuals or groups, but as a permanent attempt to lay bare and 
redress the harm and injustice caused by violence and exclusion, by restrictions of pluralism. Emancipation in this sense is not, then, to attain equality by some uncontested measure. In contrast to a traditional understanding of emancipation, and in line with the critique of rationalism, agonistic emancipation should not be conceived as a transcendence of relations of power through the use of reason. Rather, the term emancipation is meant as an umbrella that captures attempts to redress instances of what agonists variously identify as inequity, injustice, exclusion, marginalization, subordination, and violence, while acknowledging that these harms are to some extent inherent in politics. The emancipatory value of contestation lies in its capacity to allow individuals to challenge these harms and thereby possibly diminish them. In other words, agonists seek to empower citizens to challenge the harm endemic to their politics. As Connolly puts it, political contestation 'prevents injuries and injustices [...] from becoming too thoroughly naturalized, rationalized, or grounded in a higher direction in being' (1991, 93). The ineradicable nature of violence and exclusion in the agonistic conception of the political entails that the agonistic ideal of emancipation can never be fully achieved, and this is precisely why their call for emancipation is one of perpetual contestation. At the least, this has as a consequence a cosmetic change in removing the stigma of irrationality, and at best it has the material effect of reducing violence and exclusion. As Monique Deveaux points out, exactly how these harms are redressed through a politics of contestation is underdeveloped in agonistic theory $(1999,15)$.

To make this conception of contestatory politics as a means of emancipation clearer, I will illustrate it with reference to Honig's notion of the 'remainders of politics'. Honig reads Rawls's A Theory of Justice as an attempt to construe a 'reconciliation without remainders', seeking to rid the public realm of antagonism (Honig, 1993, 126-161). ${ }^{8}$ As she conceives them, the remainders of politics confront us with dilemmas, tragic situations that have no single, right resolution. They are 'undecidable', in the sense that we have no recourse to reason or a moral authority to resolve the issue without loss. Rawls's liberalism, Honing argues, engenders remainders, as any political theory does, but fails to acknowledge them as such. Criminals and eccentrics, for instance, constitute such remainders (Honig, 1993, 127).

This point can be illustrated by considering Honig's account of punishment. Rawls legitimates penal practices in A Theory of Justice as necessary to maintain the stability of just institutions in the face of those who do not conceive the sense of justice as congruent with

\footnotetext{
8 Rawls's later work fares no better on Honig's account (1993, 195-199).
} 
their good (Rawls, 1999b, 504-505). Honig's point is that Rawls, in elaborating a perspective in which the practice of punishment is thoroughly rationally justified, reconciles citizens to it to the extent that they become unwilling to challenge it because they are incapable of recognizing the arbitrariness that is inherent in the practice of punishment (Honig, 1993, 144$145,198)$ :

'Rawls imagines a practice in which there is no moral anguish, no unruly excess, no joy in another's suffering, no troublesome doubts, only a sense of justice. But justifications of punishment are not so well ordered. They always draw on a range of conflicting assumptions and beliefs (vengeance, rehabilitation, self-preservation, or, as in Rawls's own case, desert and the need for stability), and this marks punishment as a tragic situation [...]: it is never simply the right thing to do.' $(1993,146)$

The consequence, Honig argues, is that remainders remain unacknowledged because, on the one hand, well-behaved citizens are turned into complacent citizens by masking the loss that is involved in violence that is presented as fully rationally justified, and on the other hand, subjects of the penal practice are branded as irrational or unreasonable, and may therefore be legitimately coerced. In its most dramatic form, the consequence is the exercise of violence, veiled as justified by reason, rather than recognized as a sometimes prudential, but always tragic event. And so:

'[...] when [Rawls's] scheme does find itself face to face with some of its own remainders (as it does, most dramatically, when it confronts and punishes criminals, the citizens whose experience of the state as a coercive power is perhaps the least subtle or ambiguous), it is surprised, it responds quite violently, and it judges itself to be thoroughly justified in doing so. Disempowered by their reconciliation to the state and its powers, desensitized to the remainders of politics, Rawlsian citizens find it difficult to articulate or politicize this violence. But they are no less subject to it, no less parties to it.' $(1993,129)$

Honig's notion of the remainders of politics is the clearest elaboration of the harm and violence inflicted on political subjects through the marginalization and exclusion for which agonists castigate liberalism (a point that is otherwise underdeveloped in agonistic theory). To counter these effects, Honig argues, we need a politics that is radically open to contestationa repoliticization of politics: '[...] increases in justice will come with the proliferation, not the diminution, of political sites, with a politicizing rather than a conciliatory response to the state's monopoly on the administration of justice' $(1993,158,130)$. 
A couple of remarks are in order regarding my classification of Mouffe as an emancipatory agonist. Firstly, this is not meant to suggest that her account of agonism is identical to those of Honig and Connolly. In fact, in a couple of footnotes, she distantiates herself from them, suggesting that they fail to fully face up to the ineradicability of antagonism (Mouffe, 2000, 107 n. 31; 2005, 131, n. 9). Second, many of Mouffe's texts espouse a concern with maintaining liberal-democracy and safeguarding its principles in the face of the ineradicability of antagonism $(1993,2 ; 2000,104)$. The extent to which the emancipatory commitment of her early work (Laclau and Mouffe, 2001, originally published in 1985) informs this account of democracy is not entirely clear. Nonetheless, in her later work she clearly identifies democracy with challenging relations of subordination (Mouffe, 2000, 20). It seems reasonable to suggest that this capacity to challenge subordination is what drives her affirmation of democracy.

I cannot here pass a definitive judgment on this critique of liberal depoliticization, but point out that it merits further scrutiny. If rationalist and consensual liberal theories do indeed engender violence and exclusion which cannot be rendered fully legitimate, this constitutes a problem which is, from a normative standpoint, internal to liberalism. Emancipatory agonists castigate liberals for not living up to their own ideals, for not acknowledging the ways in which their reliance on a consensus to constitute a fair system of social cooperation necessarily inhibits its realization. Of course, liberals would not readily concede this point. But framing this challenge to liberal theory in terms of a call for emancipation, rather than a call for a valuation of pluralism, offers handles to engage it. It shows that the issues that divide liberals and emancipatory agonists revolve around their social ontology and moral psychology - their conceptions of power and reason-rather than their normative commitments. ${ }^{9}$

\section{Perfectionist agonism}

I have argued so far that the agonistic theory of politics as contestation and its critique of liberalism should be understood to be normatively committed to an emancipatory ideal. However, while true of the agonistic theorists considered so far, this fails to capture the full range and depth of current agonistic critiques. Specifically, we need to consider what I term perfectionist agonism. The most thorough account of it is David Owen's (1995) elaboration of Nietzschean political thought. As a critique of and alternative to liberal political thought, it is

9 This is well illustrated by Knops (2007), who criticizes Mouffe's conception of reason and deliberation. 
of philosophical significance. Although this type of agonistic theory is underdeveloped in the literature and has received little attention, it does not stand in isolation with respect to the tradition of political thought. On the one hand, it connects with a strain in democratic thought (associated with Mill, Emerson, and de Tocqueville, among others) that deplores conformist tendencies in democracy and emphasizes the need for the cultivation of perfectionist virtues (Cavell, 1990; Conant, 2001, 227-229). On the other hand, it bears a strong relation to the ancient Greek understanding of the agon that inspired both Nietzsche and Arendt, and has recently been appropriated for political theory by Karagiannis and Wagner (2005).

Like emancipatory agonism, perfectionist agonism conceives of politics as perpetual contestation of the fundamental institutions and values of a political community — as a contest without a final victor. But it argues for this from a very different normative standpoint. Perfectionist agonism values political contestation not for its capacity to challenge violence and exclusion, but for its capacity to enhance citizens' virtues and capacities - for its Bildung of better citizens. In other words, from a perfectionist standpoint, agonistic politics is primarily concerned with the good life. The following statements clearly reveal this contrast. As Honig sums up her commitment to an agonistic conception of politics:

'The perpetuity of contest is not easy to celebrate. My own affirmation of it is animated, not by the benighted teleological belief that politically active lives are necessarily fuller or more meaningful than their alternatives, but by my conviction that the displacement of politics with law or administration engenders remainders that could disempower and perhaps even undermine democratic institutions and citizens.' (Honig, 1993, 14)

Whereas for Owen:

'Politics is revealed on this civic humanist account as the highest form of human activity, the privileged locus of the good life, since it is in the arena of politics that we are concerned with the character of nobility in arguing about which virtues and values should be communally cultivated.' (Owen, 1995, 160) ${ }^{10}$

Whereas Honig explicitly does not endorse a defense of agonistic politics for the sake of the good life, for Owen the cultivation of nobility is the whole point.

10 Note that Rawls $(2005,260)$ explicitly rejects a civic humanist account of politics as fundamentally opposed to political liberalism. This already points to the divide between these conceptions of politics which I aim to show below. 
I will first sketch a basic account of perfectionist agonism and then illustrate it with reference to Owen. The perfectionist ideal requires some elaboration. It involves two moments. First, it is a striving for distinction and excellence in social practices, for ever greater words and deeds, measured by standards of excellence current in those practices. Second, it refers also to the cultivation of standards of excellence themselves, in determining which practices to engage in and which standards of excellence to adopt. In other words, perfectionism here refers not only to the cultivation of goodness, but also to the cultivation of conceptions of goodness. This double sense is what distinguishes this agonistic perfectionist ideal from liberal perfectionism, which poses a conception of autonomy as the good life (Raz, 1986). The agonistic perfectionist ideal is a striving for perfection as continuous improvement, leaving open what counts as improvement, rather than fulfillment of a preconceived ideal. What marks this perfectionism as agonistic is the insistence that cultivation of excellence requires tension and struggle. Human virtues and capacities are generated through contest with others, mutually enticing one another to ever greater achievements.

This can be illustrated by considering Owen's Nietzschean political theory. As we have seen, politics for Owen is concerned with the 'character of nobility' (1995, 132-170). Nobility here refers to Nietzsche's conception of self-overcoming - the extension of human powers and capabilities (Owen, 1995, 168-169; see also 2002). Importantly, included in this conception is the development of what count as valuable human powers and capabilities, that is, of standards of excellence. In other words, the aim is not only the achievement of greater excellence according to some specific measure, but to set a new measure of excellence to overcome the old - reflecting the two moments of the perfectionist ideal identified above.

The connection between this conception of nobility and a contestatory conception of politics requires some elaboration. For Owen (as for Nietzsche), self-overcoming, and hence the cultivation of nobility, cannot be a private affair. Underlying this link between nobility and politics is the perspectival theory of value Owen derives from Nietzsche (1995, 32-39, 139-146). On this account, standards of excellence are perspectival in nature, meaning that they are constituted by individuals' ascriptions of value to their own and others' performance in particular practices. Crucially, for an individual to adopt a value-perspective is not simply to affirm certain standards of excellence, but also involves a commitment to continuous reexamination of one's standards through an engagement with other perspectives (a commitment to self-overcoming) (Owen, 1995, 142-144, 160). In any practice, the interaction 
of a plurality of perspectives leads to some measure of public recognition for certain standards of excellence-to communal standards which are continually revised in a process of contestation. As Owen puts it, 'our practices are agonistic in a twofold sense: firstly, practices are characterised by historical communities in which persons contest with themselves and each other to achieve excellence; and, secondly, practices are characterised by the contestation of plural perspectives concerning the character of excellence' $(1995,144)$. In the contestation of perspectives, individuals challenge one another to exercise virtues and capacities in putting forth and revising their perspective, and thereby cultivate nobility. A plurality of perspectives is thus conceived as a condition for nobility; the aim is not to arrive at a shared perspective but to make plurality productive.

Politics, for Owen, is the practice 'concerned with the ranking of cultural practices and virtues, that is, politics is the practice through which the community reflects on and constitutes itself as a community' $(1995,145)$. In other words, it is the practice in which citizens determine which practices to engage in and which types of virtue to cultivate. This is why politics is conceived as a perpetual collective strife for self-overcoming concerned with the character of nobility - a struggle over what it means to lead a good life and what its conditions are. For Owen, then, politics is inextricably bound up with ethics (the good life) and with an agonistic public culture. To be committed to a conception of the good life is inherently bound up with a commitment to engage this conception with that of others; to be committed to a view of the good life is already to take a political stand.

From this perspective, Owen levels a critique of liberalism. Like emancipatory agonistic theorists, Owen charges liberal political theory with depoliticization. But on the perfectionist account, rather than undermining the emancipatory potential to challenge violence and exclusion, depoliticization stifles the development of citizens' virtues and capacities - among which, crucially, 'our capacities for autonomous reflection and agency' (1995, 138). According to Owen, depoliticization impoverishes the social and cultural resources for the cultivation of 'human powers valued by the community', in short, nobility $(1995,133,169)$. Public contestation, and thus the cultivation of nobility, is undermined by a liberal separation of public and private and a demand for state neutrality (1995, 167-168). Owen understands depoliticization as the removal of contestation on fundamental ethical questions from the public sphere. Against this, Owen suggests that politics should not be separated from a public culture of contestation through which virtues and nobility can be cultivated. As such, Owen takes head-on Richard Rorty's claim that politics should not be aimed at creating a particular 
type of human being because '[...] even if the typical character types of liberal democracies are bland, calculating, petty, and unheroic, the prevalence of such people may be a reasonable price to pay for political freedom.' (Owen, 1995, 150; Rorty, 1991, 190) According to Owen, there is no need to pay such a price because political freedom and perfectionism are not mutually exclusive. On the contrary, arguing for an exercise-concept of freedom as selfovercoming (as opposed to an opportunity-concept), Owen argues that it is precisely in the exercise of virtues and capacities in the public arena that citizens become free $(1995,164-$ 169). ${ }^{11}$

This indicates that what is at stake here are the ends of politics. From a normative perspective, the perfectionist aim of politics as cultivating conceptions of goodness constitutes an external challenge to liberal political theory. Liberals emphatically do not attempt to cultivate types of noble human being through politics. Perfectionism is a more demanding idea of the ends of politics than the liberal end of fair social cooperation. Owen is conscious of this and attempts to bridge the gap. He adopts a two-pronged strategy, trying to show on the one hand that liberals are wrong to dismiss the normative commitment to self-overcoming as an end of politics, and on the other hand that his Nietzschean version of agonistic politics not only satisfies a concern with perfectionism which liberalism cannot, but that also 'can do all the work that liberals require in terms of political freedom' (1995, 166-167). This gives rise to two sets of questions. On the one hand, one can ask whether Owen's account is radical enough; whether perfectionist agonists committed to nobility can retain as much of the liberal framework of rights as he wishes. There is nothing about perfectionist agonism that makes such an attempt to bridge the gap necessary. An account of perfectionist agonism that fails to live up to liberal standards is conceivable. Such a perspective would constitute a truly radical critique of liberal thought. On the other hand, one can ask whether Owen's account is too radical in its critique of liberal theory; perhaps liberalism can accommodate the public cultivation of excellence to a greater extent than Owen acknowledges. On this point, an engagement with deliberative democratic theory may be fruitful.

I cannot here give a full account of Owen's rich and intricate argumentation. For now, his account serves as an exemplar of a position of perfectionist agonism that can be distinguished both from liberalism and emancipatory agonism. Contrary to political liberalism, perfectionist agonism does not ask citizens to leave their fundamental ethical and philosophical

11 This distinction between the exercise and opportunity concepts of freedom was first drawn by Taylor (1985). See Siemens (2006) for an elaboration of Nietzsche's conception of freedom as the exercise of capacities. 
commitments at home when deliberating in public. And contrary to liberal perfectionism, it does not utilize public institutions to promote a specific conception of the good (one of personal autonomy). Rather, it uses the public sphere to allow citizens to generate and develop conceptions of a good and virtuous life against a background of temporary, contestable public standards the meaning of which is continually at stake. While it shares with emancipatory agonism a mistrust of liberal consensus and an emphasis on the necessity of contestation for the articulation of identities to counter the effects of homogenization engendered by liberalism, it does so from a very different normative angle.

\section{Conclusion}

I have argued that to conceive the debate between agonism and liberalism strictly in terms of an opposition between consensus and contestation, and between the accommodation of a fact of pluralism and a valuation of genuine pluralism, misrepresents the issue. We need to consider what is at stake in this debate and recognize what I have called the emancipatory and perfectionist impulses underlying the critique of liberal depoliticization. This raises important questions. Regarding the emancipatory critique, we need to ask: To what extent are violence and exclusion inherent to politics? Can a shift from consensual to more contestatory politics mitigate this? This calls for an engagement of the social ontology and moral psychology that inform liberal and agonistic thought. The perfectionist challenge, by contrast, goes further in posing the question of the ends of politics. Should we affirm the cultivation of excellence as an aim of politics? And to what extent does liberalism undermine the cultural resources for this? My hope is that this analysis will stimulate deeper engagement between agonistic and liberal theorists.

This attempt at a reconstruction of the agonistic critique from a normative-theoretical perspective is necessarily limited. Crucial issues of contention such as conceptions of the political, power, rationalism, moral psychology, the limits of pluralism, to mention a few, have remained underexamined. Furthermore, the distinction between emancipatory agonism and perfectionist agonism is neither exhaustive nor exclusive. Arguments for an agonistic conception of politics are also made on pragmatic grounds, according to which dealing with disagreement is better than attempting to overcome it (van den Brink, 2005), and for postfoundationalist theoretical concerns (Hatab, 1995). However, I submit that the issues of contention between agonistic and liberal theory can only be addressed once we get clear on the normative commitments that inform agonistic theorizing. 
Acampora, C.D. 2003, 'Demos Agonistes Redux: Reflections on the Streit of Political Agonism', Nietzsche-Studien, 32: 374-390.

Arendt, H. 1998, The Human Condition, 2nd edn, Chicago: University Of Chicago Press.

Barry, B.M. 2001, Culture and Equality : An Egalitarian Critique of Multiculturalism, Cambridge, MA: Harvard University Press.

Brady, J.S. 2004, 'No Contest? Assessing the Agonistic Critiques of Jurgen Habermas's Theory of the Public Sphere', Philosophy \& Social Criticism, 30(3): 331-354.

Cavell, S. 1990, Conditions Handsome and Unhandsome: The Constitution of Emersonian Perfectionism, Chicago: University of Chicago Press.

Conant, J. 2001, 'Nietzsche's Perfectionism: A Reading of Schopenhauer as Educator' in R. Schacht (ed.) Nietzsche's Postmoralism: Essays on Nietzsche's Prelude to Philosophy's Future, Cambridge: Cambridge University Press, pp. 181-257.

Connolly, W.E. 1991, Identity|Difference: Democratic Negotiations of Political Paradox, Ithaca, N.Y.: Cornell University Press.

Deveaux, M. 1999, ‘Agonism and pluralism', Philosophy \& Social Criticism, 25(4): 1-22.

Dryzek, J.S. 2005, 'Deliberative Democracy in Divided Societies: Alternatives to Agonism and Analgesia', Political Theory, 33(2): 218-242.

Friedman, M. 2000, 'John Rawls and the Political Coercion of Unreasonable People' in V. Davion \& C. Wolf (eds.) The Idea of a Political Liberalism, Lanham: Rowman \& Littlefield, pp. 16-33.

Habermas, J. 1996, Between Facts and Norms: Contributions to a Discourse Theory of Law and Democracy, Cambridge, MA: MIT Press.

Hatab, L.J. 1995, A Nietzschean Defense of Democracy: An Experiment in Postmodern Politics, Chicago, Ill.: Open Court.

Honig, B. 1993, Political Theory and the Displacement of Politics, Ithaca, N.Y.: Cornell University Press.

Karagiannis, N. \& Wagner, P. 2005, 'Towards a Theory of Synagonism', Journal of Political Philosophy, 13(3): 235-262.

Knops, A. 2007, 'Debate: Agonism as Deliberation - On Mouffe's Theory of Democracy', Journal of Political Philosophy, 15(1): 115-126.

Laclau, E. \& Mouffe, C. 2001, Hegemony and Socialist Strategy: Towards a Radical Democratic Politics, 2nd edn, London: Verso.

Mouffe, C. 2005, On the Political, London: Routledge.

Mouffe, C. 2000, The Democratic Paradox, London: Verso. 
Mouffe, C. 1995, 'Democratic Politics and the Question of Identity' in J. Rajchman (ed.) Identity in Question, New York: Routledge, pp. 31-42.

Mouffe, C. 1993, The Return of the Political, London: Verso.

Owen, D. 1995, Nietzsche, Politics and Modernity, London: Sage.

Owen, D. 2002, 'Equality, Democracy, and Self-Respect: Reflections on Nietzsche's Agonal Perfectionism', Journal of Nietzsche Studies, (24): 113-131.

Rawls, J. 2005, Political Liberalism, expanded edn, New York: Columbia University Press.

Rawls, J. 1999a, 'Justice as Fairness: Political Not Metaphysical' in Samuel Freeman (ed.) Collected Papers, Cambridge, MA: Harvard University Press, pp. 388-414.

Rawls, J. 1999b, A Theory of Justice, revised edn, Cambridge, MA: Harvard University Press.

Raz, J. 1986, The Morality of Freedom, Oxford: Clarendon Press.

Rorty, R. 1991, Objectivity, Relativism, and Truth, Cambridge: Cambridge University Press.

Schaap, A. 2007, 'Political Theory and the Agony of Politics', Political Studies Review, 5(1): 56-74.

Schaap, A. 2006, 'Agonism in divided societies', Philosophy \& Social Criticism, 32(2): 255277.

Schmitt, C. 1996, The Concept of the Political, Chicago: University of Chicago Press.

Sen, A.K. 2006, Identity and Violence: The Illusion of Destiny, New York: Norton.

Siemens, H. 2006, 'Nietzsche Contra Liberalism on Freedom' in K. Ansell-Pearson (ed.) A Companion to Nietzsche, Blackwell, pp. 437-437-454.

Siemens, H. 2001, 'Nietzsche's Political Philosophy: A Review of Recent Literature', Nietzsche-Studien, 30: 509-526.

Taylor, C. 1985, 'What's Wrong with Negative Liberty?' in Philosophy and the Human Sciences: Philosophical Papers 2, Cambridge: Cambridge University Press.

Tully, J. 2002, 'Political Philosophy as a Critical Activity', Political Theory, 30(4): 533-555.

van den Brink, B. 2005, 'Liberalism without Agreement: Political Autonomy and Agonistic Citizenship' in J. Christman \& J. Anderson (eds.) Autonomy and the Challenges to Liberalism, Cambridge: Cambridge University Press, pp. 245-271.

Villa, D. 1999, 'Democratizing the Agon: Nietzsche, Arendt, and the Agonistic Tendency in Recent Political Theory' in Politics, Philosophy, Terror: Essays on the Thought of Hannah Arendt, Princeton: Princeton University Press, pp. 107-127.

Waldron, J. 1999, Law and Disagreement, Oxford: Clarendon Press. 